\title{
Leveraging Government Initiatives through Facilitating the Newly Recruited Faculty Members in Engineering
}

\author{
Thanikachalam Vedhathiri, B.E., M. Tech., \\ Ph.D., M.S., FIE., FIGS., FFIUCEE., \\ Former Professor, National Institute of Technical \\ Teachers Training and Research, Chennai, \\ vthani2025@gmail.com
}

\begin{abstract}
Under the fast-changing disruptive technologies and fierce global competitions, employers are looking for industry-ready graduates with excellent attributes and innovative skills to develop state-of-art products and replace them periodically with superior products to get the lions' share of global markets. This is possible only if the institutes focus their efforts to develop outstanding faculty members. National Education Policy (NEP) 2020 provides a guideline to develop Indian Education to innovate in all spheres. In the last fifty years, there were many faculty development efforts, but none of them provided long-term impact. A study has been taken on the following issues: 1). Flawless Recruitment Process, 2). Planning and Conducting Orientation Programs, 3). Attaching them with Dedicated Mentors, 4). Planning and Implementing Continuous Professional Development Programs, 5). Conducting Appreciative Inquires and Follow up 6). Encouraging them to Undergo Advanced Research and Development Programs in the Research Universities. 7). Encouraging and Inducting them into the Ongoing Consultancy Projects, 8). Training them to Establish Interdisciplinary Graduate and Postgraduate Research and Programs, 9). Training and
\end{abstract}

Keywords: Recruitment of faculty, Mentoring. Continuous Training, Recognition of Outstanding Performance, Global Best Practices, and Suggestions.

\section{Introduction}

In the last five years, Indian engineering education institutes have grown very much. India has approximately 795 universities, 39671 affiliated universities, 1015696 teaching faculty members, and 23764960 students (undergraduate,

The service conditions of newly recruited and outstanding faculty members are very poor in many colleges. Further, there are too many

young faculty members on temporary appointments, with low salaries, and on insecurity jobs. Heavy teaching loads in
Inducting them in Planning and Conducting State, Regional, National, and International Conferences/ Seminars/Symposia, 10). Assessing their Performance and Implementing Recognition Systems for Outstanding Accomplishments, 11). Encouraging them in Planning and Implementing Diverse Global Faculty Development, 12). Facilitating them in planning Institute-Institute Collaboration, and 13.) Mentoring them to reach Higher Academic Cadres. The management should cultivate a culture of supporting and rewarding the best practices which will enable the growth of the graduates and the institute. The research on creating, supporting, and rewarding the promising newly recruited-faculty members has become essential not only to retain them but also, to serve the industries to reach national and global standards with needed human capital and technical support. The current National Educational Policy 2020 of India also focuses on these aspects, but the institutes have yet to refine their recruitment and rewarding best faculty members. This research suggests low-cost but high yielding human resource management practices to sustain the innovations in higher education and to support the knowledge-based Indian economy.

postgraduate, and research scholars). Out of this, 2934989 postgraduates and 200730 research

scholars are there. By 2031, all the affiliated colleges will become degree-awarding Tier III Teaching Universiti 
supervising the laboratory and workshop activities, with high student-teacher ratios in each class (sometimes higher than 60:1), faculty with little experience for class preparation, or proper student interaction, let alone time for research. All these pull down the students. Ultimately most of the graduates don't possess industry-specific skills, competencies, and attributes.

\section{Literature Survey}

ABET 2000 Engineering Criteria demands that engineers of the future must be trained to make intelligent decisions and enhance the quality of life on earth rather than endangering it. They must also make decisions in a professional environment in which they will have to interact with employees from both technical and nontechnical disciplines. Preparing engineering graduates to become designers of outstanding products demand accomplished faculty members. Education World stated that most of the faculty members do a terrific job, but each school has some faculty who are exceptional at what they do. Many star faculty members don't expect recognition but, as a Chief Executive Officer, you have to recognize and support them in many ways you can. Recognizing those stars in public ways can help school leaders highlight the qualities they value most. Rewarding the best faculty can help them set the standard-or even raise the bar-of faculty performance. Dana Hammer, et al. (2010) researched evidencebased criteria for excellent teaching and recommended appropriate means to acknowledge and reward teaching excellence. Based on their research, they identified the following factors: 1 . Positive and sufficient time for student-faculty contact, 2. Effective active learning, 3. Achievable, yet high expectations, 4. Respect diverse talents and ways of learning, 5. Effective communication skills, and 6 . Commitment to teaching well. Recognizing and rewarding excellent teaching in an institution helps to retain exemplary faculty members. Faculty members should engage in professional development to improve their teaching, with an emphasis on a scholarly, collaborative approach.

\section{- Use training, leadership, and management development programs to}

Recognize teaching excellence for the goals of improved student learning and faculty retention.

Hymie Rubenstein (2000) suggested rewarding university professors should be centered on a performance-based approach. He, further, suggested that:1). Performance reviews need to be replaced with rigorous and objective evaluations; 2). Performance and rewards should be linked closely; 3). Collective agreements should be replaced by flexible private-sector-style contracts for individuals that combine elements of basic employment agreements with incentives for the drive, imagination, and productivity; 4). Teaching and research should be evaluated separately; 5). Revoke the tenure of the non-scholars who did not publish; 6). Replace the university tenure systems with renewable performance-based contracts; 6). Award sabbaticals in a system of unrestricted results-oriented competition; 7). The individual ability should determine questions of academic remuneration.

Michael Armstrong and Helen Murlis (2008) published a Handbook of Remuneration Strategy and Practice. They described the concept of total reward. According to them reward policies and practices can play a significant part in change programs, helping to achieve strategic goals and underpinning the culture. But lead must come from top management (Board of Governors), which sets the direction and decides how reward management can best provide the help and support required. They suggested the following to develop a more productive employment relationship and increase faculty commitment:

- Develop performance management processes that ensure that performance and competence and competence expectations are discussed, agreed upon, and reviewed regularly.

- Encourage the use of personal development plans, which spell out a continued improvement of performance that can be achieved, mainly by selfmanaged learning.

underpin core values and define performance expectations. 
- Ensure through manager and team leader training that managers and team leaders and their team members understand their roles in managing the employment relationship, through processes such as effective use of leadership styles, performance management, and team leadership.

- Encourage the maximum amount of contact between managers and team leaders and their team members, to achieve a mutual understanding of expectations and provide a means of two-way communication.

- Adopt a general policy of transparencyensuring that on matters which affect them, employees know what is happening and the impact it will make on their employment, development, and prospects.

- Develop personnel procedures covering grievance handling, discipline, equal opportunities, promotion, and redundancy; and ensure that they are implemented fairly and consistently.

- Develop and communicate personnel policies covering the major areas of employment, development, reward, and employee relations.

All these are equally applicable to engineering education.

\section{Harvard University's Model for Recognizing their Faculty Members for "Cultivating a Culture of Appreciation":}

According to Harvard University, faculty members appreciate when others recognize their contributions and achievements. Recognition serves as a tool for reinforcing the behaviors that drive an organization to excellence and gives a vital boost to employees' engagement that has a "ripple effect" that reaches beyond the recipient. Through recognition, the managers build a culture that attracts and retains the best talent. Harvard University suggested the following to recognize the faculty members: a). Recognize the faculty member at a staff meeting, b). Send a card to the faculty you wish to recognize, c). Give your faculty a small token of recognition, c). Ask a strong performer to be a mentor in the faculty mentoring program, d). Send an email of appreciation to HOD (with a copy to the faculty), e). Ask the HOD to send an appreciative e-mail to faculty or have lunch with the faculty, and f). Post recognition notices on the website. Harvard suggested the following rules when offering recognition: i). Be genuine, ii). Be timely, iii). Be specific, iv). Give the "recognition" s/he deserves, v). Keep it rightsized, and vi) Personalize it, if you can.

"Cultivating a culture of appreciation, knowing your people, and being generally appreciated is important. We appreciate it when others recognize our contributions and achievements. As managers, our recognition lets employees know that we care about creating an environment where individuals feel appreciated for their contributions and their accomplishments. Through recognition, we also build a culture that attracts and retains the best talent".

\section{Harvard University's Suggestions:}

- Systemized and timely plans for sharing up.

- Find value in everyone's contributions.

- Variety matters.

- Sustainability.

\section{Rochester Institute of Technology's (RIT) Employee Engagement Survey}

The 2012 Collaborative on Academic Careers in Higher Education (COACHE) Survey of faculty job satisfaction and Rochester Institute of Technology (RIT) Employee Engagement Survey identified appreciation and recognition as an area of concern at RIT. According to this survey, "Faculty, at all ranks, are just like everyone else when it comes to wanting to be appreciated by colleagues and recognized for doing good work." According to the Education Advisory Board (EAB), "Strategies for improving Faculty Morale and Elevating Performance" reflects that recognition for faculty contribution-whether in teaching, research, or service-not only demonstrates the value of faculty but also reinforces faculty retention. Further, the report shows that faculty members are not always seeking a tangible award (often monetary). Faculty would likely 
appreciate some other recognition for their work such as support for improvements in the teaching environment, their research agenda, or participation in governance activities, or flexibility in teaching responsibilities, fewer course preparations, or preferred teaching schedule. The EAB study observes that recognition and appreciation can be directly tied to faculty morale. Faculty are simply seeking a "culture of comfort" that will allow them time to work on innovative or creative efforts in their courses, scholarly research, or engage in professional development activities. EAB University Leadership Council suggests, "Recognition can be done in a relatively inexpensive way, and in a public way... Showcasing faculty members who have done amazing things and having a reception to say thank you goes a long way towards developing a non-financial currency for recognition".

EAB Strategies for Improving Faculty Morale and Elevating Performance are:

- Transparency and equity in the merit review process,

- Recognition for contributions to teaching, research, and service,

- Support for improvements in teaching and research,

- Participation in the decision-making process within the department, college, and broader institution.

Ohio State University's "Principles for Faculty Reward Systems in HighPerformance Academic Culture"

- Focus on developing all aspects of a high performing culture in which outstanding achievements are aligned with carefully guided decisions about resource allocations.

- Guide through continuous coaching research contributions.

- Develop policies guiding the faculty reward system that are clear and equitable.

- Recognize achievements in multiple dimensions like research, teaching, and service.

\section{Faculty Handbook}

IIT Bombay (2014) brought out a Handbook to the faculty members on governing structure, needed information for new faculty members, what IIT expects from them, teaching at IIT, continuing education programs, consultancy, accepting directorship in companies, starting a company based on their research/technological breakthroughs, self-assessment and promotion to higher posts, ethics and conduct, salary, allowances and other benefits leave and vacation and retirement benefits. This is an outstanding publication that provides all the needed information to the newly recruited faculty members. All institutions should emulate.

\section{Faculty Contribution to Society}

Jennifer Lundquist (2016) stated that engaging the larger public and influencing policy through one's scholarship can personally rewarding, but such work too often goes unrecognized in university systems. According to her many faculty members were drawn to research because of its potential to contribute to society. These faculty members feel strongly that what they do matters to the large world, whether their work is primarily theoretical or aimed at direct application. Believing it important to engage the larger public and influence policy, such faculty make efforts to do so through blogs, news reporters, social media, and presenting their projects to citizens. Public engagement has many potential benefits. It can advance public understanding of scholarly knowledge and help influence policy agendas and policymaking.

Christina Wood (2018) stated that 49 percent of employees quit when recognition is lacking. She suggested to reward with praise, make it public, personalize the gifts, reward with swag, and choose a good reward. Jeffery Bodimer (2009) suggested using training and development to motivate staff.

All India Council for Technical Education (AICTE) developed a comprehensive training policy for technical teachers. This includes faculty induction program, orientation towards technical education \& curriculum aspects, professional values, ethics, ecology \& sustainable development, communication skills, 
modes, and knowledge dissemination, instructional planning and delivery, teaching enabled learning \& lifelong self-learning, effective modes of student assessment and evaluation, creative problem solving, innovation and meaningful $R \& D$, institutional management and administration procedures. There is a focus on a disruptive digital-technologies. Also, it has prescribed any continuous training or any industrial exposure. Community Tool Box prepared a detailed note on developing staff orientation programs. This organization has also developed a plan for staff hiring and training.

AICTE has indicated research \& innovations development schemes for the engineering institutions. Industrial Research \& Development Unit (IRD) of IIT Delhi (2009) brought out comprehensive information on sponsored research projects and consultancy jobs for their faculty members. Imperial College, London published a note on industrial partnerships and commercialization. Virtual Reality (VR) is one of the current trending technologies that allows computer-generated imagery to be overlaid onto simulated environments. The concept of VR refers to a whole simulated reality, built with computer systems by using digital formats that require hardware and software. Sarah El- Mallah and Tonia Dousay (2019) encouraged faculty adoption of virtual reality tools in engineering education.

Veronica Diaz et al. (2009) explored faculty development for the $21^{\text {st }}$ century. They suggested three-tier programs (Table-1)

Table. 1 Audience and Programs

\begin{tabular}{|l|l|}
\hline \multicolumn{1}{|c|}{ Audience } & \multicolumn{1}{c|}{ Programs } \\
\hline $\begin{array}{l}\text { Graduate Students and } \\
\text { Teaching Assistants }\end{array}$ & $\begin{array}{l}\text { Basic instructional strategies and methodologies, } \\
\text { Introduction to learning technologies. }\end{array}$ \\
\hline New Faculty Members & $\begin{array}{l}\text { Mentoring with senior faculty, } \\
\text { Exposure to institutional policies. }\end{array}$ \\
\hline $\begin{array}{l}\text { Established Faculty } \\
\text { Members }\end{array}$ & $\begin{array}{l}\text { Institutional orientation, } \\
\text { Support for new instructional models, } \\
\text { Technologies, and pedagogies, } \\
\text { Advanced course management system support. }\end{array}$ \\
\hline
\end{tabular}

The National Institute for Design Learning (NIDL), of Dublin City University, Ireland, provides a range of consultancy services to institutions. This institute offers appropriate teaching enhancement courses and professional development programs in digital learning (http://www4.dcu.ie/nidl/contact.shtml).

Mark Crawford (2012) suggested 9 selfimprovement strategies for engineers. The strategies are:1. Learn the business, 2. Know your customers' competitive market place, 3 . Learn the upstream supply chain, 4 . Don't stop learning, 5. Keep your technical skills current, 6 . Find a coach, 7. Seek out new challenges and challenging assignments, 8. Critique your performance, and 9. Think about the next step in your education. Abouelenein and Yousri Attia Md. (2016) suggested training the faculty members towards achieving the quality of university education in the light of technological innovations. Mona Heolmquist (2018) concluded that a lack of qualified teachers is a global challenge for future knowledge capital. Mohan Reddy (2019) developed a report entitled "Engineering Education in India-Short \& Medium-Term Perspectives" for AICTE. He recommended introducing undergraduate engineering programs exclusively focused on AI, IoT, Blockchain, Robotics, Quantum Computing, Data Sciences, Cyber Security, 3D Printing \& Design, AR/VR, etc. He further recommended a greater focus on multidisciplinary engineering courses and reducing seats in conventional disciplines and organizing cutting-edge courses in these fields. National Science Foundation (2020) announced the details of needed proposals in research as a part of research experiences for engineering teachers. Many institutions have planned and executed induction programs. Some of the significant programs are shown in Table-2. 
Table-2. Induction Programs for the newly recruited faculty members

\begin{tabular}{|l|l|l|}
\hline No. & \multicolumn{1}{|c|}{ Organizer } & \multicolumn{1}{c|}{ Focused Areas } \\
\hline 1 & $\begin{array}{l}\text { Gujarat } \\
\text { Technological } \\
\text { University }\end{array}$ & $\begin{array}{l}\text { Teaching and learning, pedagogical interventions for innovation, Academic } \\
\text { performance indicators (API), On-line teaching-learning and MOOCs, virtual } \\
\text { labs, Outcome-based education \& NBA Graduate attributes, Human values \& } \\
\text { professional skills, C.O, P.O, P.S.O,/ P.E.O and their mapping, Bloom's } \\
\text { taxonomy and Learning objectives, Project-based learning, and Instructional } \\
\text { methods. }\end{array}$ \\
\hline 2 & $\begin{array}{l}\text { Osmania } \\
\text { University }\end{array}$ & $\begin{array}{l}\text { Flexible and effective governance, Autonomy and decentralization, Academic } \\
\text { programs relevant to the social and economic needs of the nation in general } \\
\text { and the region in particular, networking with other centers/departments and } \\
\text { laboratories in the country and abroad. }\end{array}$ \\
\hline 3 & $\begin{array}{l}\text { UGC } \\
\text { Challenges in higher education, Higher education and human values, } \\
\text { University-society relationship, Curriculum, and pedagogy: Contemporary } \\
\text { needs, Reforms in higher education, Research in higher education, Outreach, } \\
\text { and Extension activities. }\end{array}$ \\
\hline $\begin{array}{l}\text { Teaching } \\
\text { Center } \\
\text { Coimbatore } \\
\text { Institute } \\
\text { Technology }\end{array}$ & $\begin{array}{l}\text { Roles and responsibilities of a faculty/academics in higher education; } \\
\text { University structure and functioning; Curriculum Design and content } \\
\text { development; Pedagogic technics and teaching-learning methods; Assessment } \\
\text { and Evaluation; Research in higher education; Personal-emotional } \\
\text { Development and Counseling; ICT: Effective use of technology for teaching, } \\
\text { learning and evaluation; E-Content development, MOOCs; University } \\
\text { governance and administration; Academic leadership; and Strategic planning } \\
\text { and management. }\end{array}$ \\
\hline
\end{tabular}

NITTTR Bhopal (2018) has developed a list of duties of various cadres of the faculty members. This will provide guidelines to contribute to the mission and personal satisfaction. Further, a faculty can present her/his accomplishments for further selection to higher cadres.

\section{Draft National Education Policy 2019 (Chapter 13)}

The following are the suggestions of the Draft National Education Policy 2019:

- Create adequate physical infrastructure, facilities, and improve service conditions ( $\mathrm{p} 256$ ).

- Fill up the vacancies based on academic expertise and depth, on teaching capacities and dispositions for public service.

- Provide autonomy to the faculty.

- Enable vibrant university communities through faculty empowerment.

- Motivate faculty to become creative and innovative in presentation, content, and assignments.
- Motivate and energize faculty to achieve high quality in higher education.

- Improve service conditions, performance management, career progression, and institutional leadership.

- Incentivize excellence through meritbased career management.

- Incentivize the faculty to spend their energies on achieving personal and institutional excellence to spend their energies on achieving personal and institutional excellence in teaching, research, and service.

- Provide time for creative class preparation, innovative research, and service.

- Chose institutional leadership based on merit without any time gap for developing a culture of excellence and high performance.

- Empower faculty to make curricular choices for their courses and pursue research with academic freedom. 
- Ensure service conditions conducive to excellent teaching and research.

- Create a culture of excellence through outstanding institutional leadership.

- Mentor by senior academics.

- Faculty recruitment, and development, career progression, and compensation management should be part of the institutional development plan.

\section{Inferences}

Almost all universities which are high performing in teaching, research, and services have focused on the needed culture, recognition, rewarding, engagement of the stars to retain them and create an academic ecosystem for undertaking advanced and complex research work. National Educational Policy 2019 also focused on the existing deficiencies and suggested measures to overcome all deficiencies.

\section{Continuous Professional Development (Section5.15-CPD)}

New Education Policy 2020 states that "Teachers will be given constant opportunities for self-improvement and to learn the latest innovations and advances in their profession. To ensure that every teacher has the flexibility to optimize their development as teachers, a modular approach to continuous teacher development will be adopted. Development opportunities, in the form of local, state, national, and international teaching, and subject workshops, as well as online teacher development modules, will be available to all teachers so that each teacher may choose what is most useful for their development. Platforms (especially online platforms) will be developed so that teachers may share ideas and best practices. Each teacher will be expected to participate in, say, 50 hours of CPD opportunities every year for their professional development, driven by their own needs and choice".

\section{Objectives of Research}

- To identify specific deficiencies in the engineering institutes in recruiting promising young faculty members, fixing the salary, coaching them to undertake the state projects, and training them in the instructional methods.

- To critically review the suggestions of National Education Policy (NEP) 2020 in recruiting, developing the faculty, and rewarding the best performing faculty members.

- To suggest appropriate training programs as per NEP 2020 for lifelong development of the newly recruited faculty and the supportive culture and educational ecosystem which will ensure excellent resources, funds, motivation, and ethics.

\section{Research Methodology}

Qualitative research, survey, observation and discussion. Suggestions from Faculty Quality Development Circles (FQDC).

Population: Young faculty members like teaching assistants, lecturers, and assistant professors in affiliated colleges that offer certificates, bachelor, and master degree programs.

\section{Sample Size}

120 newly recruited faculty members (teaching assistants, lecturers, and assistant professors) from 12 affiliated colleges and one autonomous college from the southern states who have completed 2 to 5 years of service and offer graduate and postgraduate programs in engineering and technology. A few of them conduct employee development courses and offer full-time and part-time master the degree programs.

\section{Faculty Quality Development Circles (FQDC)}

Four quality development circles (FQDC) have been constituted under educational management development programs. Each program accommodated 32 participants. In each Faculty Quality Development Circle 8 faculty members have been selected through a random process. Each FQDC was allotted one area of faculty recruitment and development process. The 
outcomes are presented in the following sections along with the guidelines of NEP 2020.

\section{Step: 1. Flawless Recruitment Procedures}

Section 5.2, $5.17 \& 13.6$ of NEP 2020 States that "In keeping with the vision, autonomous institutions are empowered to drive excellence. Higher Education Institutes shall have clearly defined, independent, and transparent processes and criteria for faculty recruitment." Based on this, the following steps are suggested:

1. Flow the AICTE prescription;

2. Evaluate the professional accomplishments of the applicants;

3. Verify the certificates and credentials;

4. Assess the motivation and vision;

5. Check their readiness to plan and implement innovative programs;
6. Check their capability to bid for consultancy projects under International Development Agencies (IDA);

7. Assess their attitudes to undertake dissertation projects based on the needs of MSMEs, and government departments;

8. Assess their abilities to offer multidisciplinary research and development works;

9. Ensure their leadership potential (Section 9.5, 10.14, 11.2, 12.2, of NEP 2020);

10. If shortcuts are made to eliminate the well-accomplished candidates will cause disastrous to the growth of the institutes and the skills and competencies of the graduates (Table$3)$.

Table-3 Flawless Recruitment Process

\begin{tabular}{|l|l|}
\hline \multicolumn{1}{|c|}{ Rules } & \multicolumn{1}{|c|}{ Operation } \\
\hline Qualification, & Don't reduce the Qualifications, Years of Experience, Publications in the Peer \\
Length of & Reviewed Journals, and National and International Conferences, Textbooks, \\
Experience, & Monographs, Drawing Manuals, Book Chapters, etc. Awards received. \\
Publications, & \\
Awards, etc. & \\
\hline
\end{tabular}

Step: 2. Planning and Conducting Induction, Orientation, and Faculty Development Programs (Section 5.15, 13.1, 13.4, 17.5, 19.1, 23.2, $23.8 \& 23.10)$ of NEP 2020.

- The ways faculty members are recruited and trained constitute their first impressions of the institutions, and contribute to how they feel about the long-term, and how good a job they do.

- Scheduling the training programs would reflect what the administrator wants the institution to be.

- cover which areas, the role of the Board of Governors, who supervises whom, communication channels, institution policies and procedures, any specific rules or regulations the institution or faculty might be subject to, etc.

- The vision and mission of the institution.
- Express institute's policies on affirmative action/ equal opportunity guidelines.

- New faculty members, regardless of their experiences and skills, need timely and time-limited orientation to their positions and to the institution itselfhow it operates, who are other faculty members are.

- The structure and general functioning of the institution-which positions

- The institution culture-how faculty treat one another, and what kind of work behavior is considered "normal".

- Believe that training is an educational process that continues throughout faculty member's working life and that the more faculty members can learn that relates to their work, and the more competence they acquire, the more innovative and competent they will be. 
- Provide a Handbook on the policies, resources, assistance, funding for research, planning new innovative programs, consultancy projects, publications like textbooks, laboratory manuals, drawing manuals, item banks, Multi-Media Learning Packages (MMLP), etc.

- Prepare modules on the following topics and provide them to the faculty members.

- Prepare a one-week schedule and operate and get the feedback from the participants.

- Project a few videos on the significant achievements of the institute.

- Plan tours to industries.
- Conduct seminars on advances in educational technology and management.

- Create learning circles.

- Plan monthly faculty meeting.

Topics for Induction and Lifelong Learning and Competency-based Programs

Duration: One week to one month in a year in the first five years; then one to two weeks per year for the next 10 years; and then one day to three days for the rest of their service. Encourage the faculty members to undergo one appropriate MOOC under EDX/Coursera/WBI, etc. After getting the certificate, reimburse the fees paid. Plan flexible courses and schedule them to suit the institute's academic activities (Table 4).

Table-4 Planning Training and Development Programs

\begin{tabular}{|c|c|c|c|c|}
\hline $\begin{array}{l}\text { Qualification of the } \\
\text { newly recruited faculty }\end{array}$ & $\begin{array}{l}\text { Engineering } \\
\text { Degrees \& } \\
\text { Engineering } \\
\text { Education } \\
\text { (MOOCs in } \\
\text { Curriculum } \\
\text { Planning, } \\
\text { Instructional } \\
\text { Design, Learning } \\
\text { Resources } \\
\text { Development, } \\
\text { Evaluation, and } \\
\text { Accreditation). }\end{array}$ & $\begin{array}{l}\text { Services: } \\
\text { Sponsored } \\
\text { Research, } \\
\text { Consultancy } \\
\text { Projects, } \\
\text { Continuing } \\
\text { Education, etc. }\end{array}$ & $\begin{array}{l}\text { Educational } \\
\text { Management: } \\
\text { Leadership, } \\
\text { Institutional } \\
\text { Development, } \\
\text { Creating } \\
\text { Excellent } \\
\text { Centers, Global } \\
\text { Networking, etc. }\end{array}$ & $\begin{array}{l}\text { Digital } \\
\text { Technology/ ICT, } \\
\text { IoT, AI, Robotics, } \\
\text { Cyber Security, } \\
\text { 3D Printing, Big } \\
\text { Data \& Analytics } \\
\text { Blockchain, } \\
\text { AR/VR }\end{array}$ \\
\hline B.E/B.Tech. & $\begin{array}{l}\text { Offer Part-time M. } \\
\text { Tech./M.E. } \\
\text { Programs }\end{array}$ & $\begin{array}{l}\text { Introduce } \\
\text { concepts, } \\
\text { models, etc. }\end{array}$ & $\begin{array}{l}\text { Introduce the } \\
\text { concepts, } \\
\text { models, etc. }\end{array}$ & $\begin{array}{l}\text { Introduce the } \\
\text { new concepts } \\
\text { through } \\
\text { workshops. }\end{array}$ \\
\hline M.E./M. Tech. & $\begin{array}{l}\text { Offer a Ph.D. } \\
\text { program. }\end{array}$ & $\begin{array}{l}\text { Involve as an } \\
\text { intern. }\end{array}$ & $\begin{array}{l}\text { Offer short- } \\
\text { term courses. }\end{array}$ & Do \\
\hline $\begin{array}{l}\text { M.Sc. } \\
\text { (Science/Mathematics) }\end{array}$ & $\begin{array}{ll}\text { Offer } & \text { Ph.D. } \\
\text { Program. } & \end{array}$ & Do & Do & Do \\
\hline Ph.D. (Engineering) & $\begin{array}{lr}\text { Approve } & \text { to } \\
\text { undertake MOOCs } \\
\text { And } & \text { self- } \\
\text { instructional } & \\
\text { modules. } & \end{array}$ & $\begin{array}{l}\text { Include in the } \\
\text { project and } \\
\text { motivate to bid } \\
\text { for new projects. }\end{array}$ & $\begin{array}{l}\text { Involve in } \\
\text { leadership } \\
\text { development } \\
\text { activities. }\end{array}$ & $\begin{array}{l}\text { Offer advanced } \\
\text { courses. }\end{array}$ \\
\hline $\begin{array}{l}\text { Ph.D. (Mathematics/ } \\
\text { Science) }\end{array}$ & $\begin{array}{l}\text { Conduct in-house } \\
\text { workshops. }\end{array}$ & Do & Do & Do \\
\hline $\begin{array}{l}\text { Ph.D. } \\
\text { (Communication) }\end{array}$ & Do & Do & Do & Do \\
\hline Ph.D. (Management) & Do & Do & Do & Do \\
\hline $\begin{array}{l}\text { Ph.D. } \\
\text { Science) }\end{array}$ & Do & Do & Do & Do \\
\hline
\end{tabular}


Desired outcomes of induction, orientation, and lifelong training and development programs

- They will have a clear understanding of the institution, their positions, and the community. They will jump into their jobs immediately and contribute.

- New faculty acquire confidence in their ability.

- They will become effective and confident to contribute to knowledge capital and human capital.

- They can communicate with others in other departments and collaborate with ongoing projects.

- They will stay in this organization for a long time.

- The administrators should value the human capital and there is no shortcut.

Step: 3. Attaching them with Dedicated Mentors (Draft NEP 2019 $P$ 14.3.4 and Section 15.11 of NEP 2020)

The newly joined faculty shall need counseling, coaching and mentoring during various phases of their career. Mentors should be accessible to guide to plan consultancy projects, planning new courses, undertaking a complex consultancy project. It is assumed that the mentors have all expertise and very successful in their academic accomplishment.

\section{Mentoring Process:}

Assumption: The mentor is like a saint and ready to share his expertise at any time. S/he will be an expert to solve many problems of the newly recruited faculty members.

- Answering the doubts,

- Guideline to plan the complex works,
- Getting the tax exemptions for the projects, if any,

- Choosing the team members for consultancy projects

- Developing technical and financial proposals for bidding global projects,

- Getting approval from the Board of Governors,

- Implementing the project schedule as per the agreement,

- Planning a seminar and conducting training programs,

- Publication of learning package,

- Settling the project accounts.

Step: 4. Planning and Conducting Continuous Professional Development (CPD) Programs (Section 17.5 and 19.5 of NEP 2020)

\section{Purpose}

The faculty members are to be engaged productively. The resources are to be shared for creative activities. The letters of invitations have to be made available to the faculty. Also, their proposals are to be forwarded to the project officials (Section 17.5 of NEP 2020).

- Undertake a new project as requested by the Ministry of Education,

- Prepare a state-of the-art report,

- Undertaking interdisciplinary research,

- Undertaking a sponsored research and development project,

- Bidding for a global project under an IDA,

(Table- 5)

Table-5.0 Faculty Development, Progress, and Academic Audit

\begin{tabular}{|l|l|l|l|l|l|}
\hline $\begin{array}{l}\text { Faculty } \\
\text { Background }\end{array}$ & Experience & $\begin{array}{l}\text { Planning new } \\
\text { faculty } \\
\text { development } \\
\text { programs }\end{array}$ & $\begin{array}{l}\text { Quarterly } \\
\text { progress on the } \\
\text { implementation } \\
\text { of seminars, } \\
\text { publications, etc. }\end{array}$ & $\begin{array}{l}\text { Half Yearly } \\
\text { outcome of the } \\
\text { projects/ } \\
\text { research } \\
\text { works/ } \\
\text { consultancy } \\
\text { projects }\end{array}$ & $\begin{array}{l}\text { Annual Academic } \\
\text { Audit } \\
\text { overall } \\
\text { of }\end{array}$ \\
therformance \\
\hline B.E/B.Tech. & $1-5$ years & $\begin{array}{l}\text { Can plan a } \\
\text { short course }\end{array}$ & $\begin{array}{l}\text { Should prepare a } \\
\text { synthesis }\end{array}$ & $\begin{array}{l}\text { Can prepare a } \\
\text { short report if }\end{array}$ & $\begin{array}{l}\text { Should present an } \\
\text { overall report and }\end{array}$ \\
\hline
\end{tabular}




\begin{tabular}{|c|c|c|c|c|c|}
\hline & & $\begin{array}{l}\text { and submit it } \\
\text { for approval. }\end{array}$ & & $\begin{array}{ll}\text { s/he } & \text { is } \\
\text { involved. }\end{array}$ & $\begin{array}{l}\text { the problems } \\
\text { faced. }\end{array}$ \\
\hline $\begin{array}{l}\text { M.E./M. } \\
\text { Tech. }\end{array}$ & $1-10$ years & Do & Do & Do & Do \\
\hline Ph.D. & $1-15$ years & $\begin{array}{l}\text { Can plan } \\
\text { faculty } \\
\text { development } \\
\text { programs in } \\
\text { research and } \\
\text { development. }\end{array}$ & $\begin{array}{l}\text { The presentation } \\
\text { of papers is to be } \\
\text { presented. } \\
\text { Follow up action } \\
\text { is to be } \\
\text { identified. }\end{array}$ & $\begin{array}{l}\text { Outcomes of } \\
\text { the research } \\
\text { projects like } \\
\text { papers, } \\
\text { innovations, } \\
\text { and } \\
\text { intellectual } \\
\text { properties are } \\
\text { to be } \\
\text { projected. }\end{array}$ & $\begin{array}{l}\text { Accomplishments } \\
\text { have to be } \\
\text { synthesized. }\end{array}$ \\
\hline
\end{tabular}

Y: Yes NA: Not applicable N: No

Step: 5. Conducting Appreciative Inquiry, Objective Evaluation and Follow up (Section 18.8 of NEP 2020)

Appreciative inquiry focuses on the positive performance of the faculty members and gives the opportunity to revise the pitfalls and mistakes. The Inquiry Officer will not find fault for the mistakes, but motivate the faculty to explore for excellence.
- Once a year for Assistant Professors/Associate Professors/Professors

- Once a year for the achievement of the whole department

- Encourage self-directed learning selfanalysis of performance. (Table-6).

Table-6. Appreciative Inquiry on the Performance

\begin{tabular}{|l|l|l|l|l|}
\hline Faculty & $\begin{array}{l}\text { Classes conducted/New } \\
\text { Programs implemented }\end{array}$ & Research Projects & $\begin{array}{l}\text { Global } \\
\text { Projects }\end{array}$ & $\begin{array}{l}\text { Problems faced and } \\
\text { desired suggestions to } \\
\text { overcome. }\end{array}$ \\
\hline $\begin{array}{l}\text { Assistant } \\
\text { Professors }\end{array}$ & $\begin{array}{l}\text { Achievements \& Short } \\
\text { Falls }\end{array}$ & $\begin{array}{l}\text { Outcome \& } \\
\text { Publications. }\end{array}$ & Outcome & Do \\
\hline $\begin{array}{l}\text { Associate } \\
\text { Professors }\end{array}$ & Do & Do & Do & Do \\
\hline Professors & Do & Do & Do & Do \\
\hline Deans & Do & Do & $\begin{array}{l}\text { Do } \\
\text { Peveloping } \\
\text { faculty, } \\
\text { Adjunct } \\
\text { faculty } \\
\text { performing } \\
\text { teams } \\
\text { given topics/ projects. }\end{array}$ & $\begin{array}{l}\text { Their } \\
\text { excellence has to } \\
\text { be evaluated. } \\
\text { analyzed have to be } \\
\text { solutions are to be } \\
\text { found. }\end{array}$ \\
\hline
\end{tabular}

Step: 6. Encouraging the Faculty Members to undergo Advanced Research and Development Programs in the Research Universities (Section 18.2 \& 18.3 of NEP 2020)

NEP 2020 States that "High-quality institutional leadership is extremely important for the success of an institution and its faculty. Various outstanding faculty members with high academic and service credentials as well as demonstrated leadership and management skills will be identified early and trained through a ladder of leadership positions. Leadership positions shall not remain vacant, but rather an overlapping period during transitions in leadership shall be the norm to ensure the smooth running of the institutions. Institutional leaders will aim to create a culture of excellence that will motivate and incentivize teaching, 
research, institutional service, and community outreach from faculty members."

Many new programs of MHRD like GIAN and India-USA $21^{\text {st }}$ Century Knowledge Initiative are available for collaboration with research universities. The faculty have to plan for research projects.
Many outstanding faculty members who apply for fellowships through proper channels will get the fellowships. They have to be timely relieved to join. A few CEOs don't permit them even though their application was routed through the CEO. Such acts don't contribute to the reputation of the institute and also another faculty member can't be substituted in the place of first selected candidates. The loss will affect the growth of knowledge capital (Table-7).

Table -7. Advanced-Research and Development Programs

\begin{tabular}{|l|l|l|l|l|l|}
\hline $\begin{array}{l}\text { Faculty } \\
\text { Background }\end{array}$ & $\begin{array}{l}\text { Summer } \\
\text { Schools }\end{array}$ & $\begin{array}{l}\text { Part- } \\
\text { time/ } \\
\text { Full- } \\
\text { time } \\
\text { Ph.D. }\end{array}$ & Fellowship & $\begin{array}{l}\text { Presenting papers in } \\
\text { the national and } \\
\text { international seminars } \\
\text { and conferences }\end{array}$ & $\begin{array}{l}\text { Interdisciplinary } \\
\text { Research }\end{array}$ \\
\hline $\begin{array}{l}\text { Assistant } \\
\text { Professors }\end{array}$ & $\begin{array}{l}\text { Should } \\
\text { apply. }\end{array}$ & $\begin{array}{l}\text { Should } \\
\text { apply as } \\
\text { early as } \\
\text { possible. }\end{array}$ & $\begin{array}{l}\text { Can apply } \\
\text { for an a } \\
\text { fellowship. }\end{array}$ & $\begin{array}{l}\text { Can prepare } \\
\text { synopsis/abstract and } \\
\text { get it reviewed. }\end{array}$ & $\begin{array}{l}\text { May join an } \\
\text { interdisciplinary } \\
\text { research team. }\end{array}$ \\
\hline $\begin{array}{l}\text { Associate } \\
\text { Professors }\end{array}$ & Yes & Yes & Yes & Yes & $\begin{array}{l}\text { Should apply for } \\
\text { research projects. }\end{array}$ \\
\hline Professors & $\begin{array}{l}\text { Should } \\
\text { prepare } \\
\text { themes for } \\
\text { organizing. }\end{array}$ & $\begin{array}{l}\text { Should } \\
\text { guide } \\
\text { research } \\
\text { scholars. }\end{array}$ & $\begin{array}{l}\text { Should } \\
\text { apply for } \\
\text { senior } \\
\text { fellowships. }\end{array}$ & $\begin{array}{l}\text { Should plan seminars, } \\
\text { workshops, and } \\
\text { conferences. }\end{array}$ & $\begin{array}{l}\text { Should lead a team. } \\
\end{array}$ \\
\hline
\end{tabular}

Step: 7. Encouraging and Inducting the Newly Recruited Faculty Members into the Ongoing Consultancy Projects (Section 17.5, 23.2 and 23.3 of NEP 2020)

The newly recruited faculty will have to maintain close collaboration with industry and institutions to drive innovations (NPE 2020, Section 17.5). They have to gain confidence and eradicate fear for undertaking consultancy projects. They can acquire the needed skills to plan, prepare bid documents, negotiate, draw contracts, and implement. Here mentoring is very essential. This approach will help the faculty members to remain highly productive and retention.

Step: 8. Training them in the Established Interdisciplinary Graduate and Postgraduate Research and Development Programs (Section 11.8, 11.10, 11.11, 11.13, \& 12.3 of NEP 2020)

The newly recruited faculty members have to understand the skills and competency requirements in planning industry-specific programs. In the long run, they have to take the development of cutting-edge programs to meet the needs of Industry-4.0. They should review the trends in innovative programs and try to prepare outstanding proposals. This step would improve learning outcomes and development of the cognitive skills of students and facilitate access to research and consultancy projects. It would enable faculty autonomy to innovate and excel. Further, the faculty can contribute to human capital development and regional competitiveness.

Step: 9. Training and Inducting them in Planning and Conducting State, Regional, National, and International Conferences/ Seminars/ Symposia (Section 19.1, 19.5 of NEP 2020).

There is a need for planning various seminars and conferences to exchange the outcomes of advanced research work. These conferences will 
facilitate the collaboration with leading universities and training the faculty members.

Step:10. Assessing their Performance and Implementing Recognition Systems for Outstanding Accomplishments (Section 13.5, 13.7, 19.2 \& 19.4 of NEP 2020)

The administrators have to plan an annual assessment of the excellence of their faculty at the national and international levels. The outstanding accomplishments are to be recognized and to be included in the annual reports. The suppression practices are to be stopped forever. If it continued, the morale of the faculty will be destroyed. Court cases will be increased. The reputation of the institute has to be maintained.

Step: 11. Encouraging them in Planning and Implementing Diverse Global Faculty Development Programs (Section 12.8 of NEP 2020)

Many Engineering Institutes have planned and implementing diverse global faculty development since 1975. There are many International organizations like GIZ, SIDA, UNESCO, UNDP, USAID, and World Bank that offer funds for undertaking diverse global faculty development programs. Ministry of External Affairs (MEA), Ministry of Finance (MF), Indian Council for Cultural Relations (ICCR), Colombo Plan Staff College (CPSC) for Technician Education, Manila, Philippines, UNESCO's Asia and Pacific Educational Innovation for Development (APEID) Bangkok, etc. offer more opportunities for planning and implementing diverse global faculty development programs. The CEOs should not obstruct the innovative global programs.

Step: 12. Facilitating them in Planning in Institute-International Research Universities Collaboration (Section 12.3, 12.8, 13.5 \& 17.5 of NEP 2020)

There is a need for planning joint research projects in collaboration with the research universities. This will assist in the development of high performing faculty teams. Section 17.5 of NEP 2020 prescribes that India must take the lead in preparing professionals in cutting-edge areas that are fast gaining prominence, such as Artificial Intelligence (AI), 3-D machining, big data analysis, and machine learning among others in technical education, genomic studies, biotechnology, nanotechnology, neuroscience and so on. The Institute administrators have to facilitate the transformation.

Step: 13. Facilitating them to reach High Academic Cadres (Section 13.6, $13.7 \& 19.4$ of NEP 2020)

MHRD introduced Higher Academic Grade (HAG) long back but many centrally funded institutes did not implement. Section 19.4 states that outstanding leaders will be identified, and developed early, working their way through a leadership position. Without outstanding faculty teams, there can't be any industry-ready graduates, and generation of knowledge capital. The performance in developing interdisciplinary programs from undergraduate to doctoral programs are to be planned in emerging technologies. Recognizing outstanding performers will alone motivate other faculty members to perform.

\section{1) The Outcome of the Faculty Quality Development Circles (FQDC)}

The following suggestions have been provided by the FQDC that deliberated on the issues:

- The best faculty recruitment process should be implemented in all institutions.

- Ethical standards are to be followed in probation completion.

- Institutes should implement faculty development through short-term, longterm, QIP, MOOCs, and programs under bilateral agreements, and IDAs.

- The CEO should encourage the high performing faculty teams in undertaking various innovative projects and multidisciplinary programs.

- The Institutions should establish institute-institute collaborations and cooperations for undertaking joint projects and international conferences.

- The Board and CEO must encourage the development of global leadership and 


recognize the outstanding
accomplishments of the high
performing faculty teams.

\section{Conclusions}

The Boards and the CEOs have the responsibility to cultivate, support, delegate, and empower high-performing faculty teams to create needed human and knowledge capitals.

Many institutes do not indicate the job specification, salary, and other conditions in the advertisements for faculty recruitments.

National Education Policy 2020 prescribed the best recruitment process and rewarding the best performers.

The existing bottlenecks in recruiting, confirming the completion of probation, training, and developing through innovative blended methods, supporting, planning, and developing multidisciplinary postgraduate and doctoral programs, conducting international conferences, networking with the global research universities, and jointly working on the cutting- edge projects.

Ethical policies are to be implemented to reach excellence. Identification of stars of high performing teams is very essential and supporting them, empowering them, and recognize their accomplishments in creating knowledge and human capital. There is no shortcut from the ethical practice. All these would ensure the performance of the engineering graduates in the industries.

\section{References}

1.Abouelenein, Yousri Attia Mohamed. (2016). Training Needs of Faculty Members: Towards Achieving Quality of University Education in the Light of Technological Innovations. Educational Research and

Reviews.11(13):1180-1193.

DOI:10.5897/ERR2015.2377

https://files.eric/fultext/EJ1106283

2.All India Council for Technical Education (AICTE). (2020). Research and Innovations Development Schemes. New Delhi. http://aicte- india.org/schemes/research-innovationsdevelopment-schemes

3.AICTE. (2017). A Comprehensive Training Policy for Technical Education. New Delhi.

4.Ashlee McGandy. (2020). Twenty new Engaged Faculty Fellows named. Cornell Chronicle.

https://news.cornell.edu/stories/2020/09/twenty -new-engaged-faculty-fellows-named

5. Anne Marie Canale, Cheryl Herdklotz, and Lynn Wild. (2014). Inspiring a Culture of Appreciation@ @IT. Wallace Center- Faculty Career Development Services. Retrieved from: https://rit.edu/academicaffairs/sites/rit.edu.acad emicaffairs/files/docs/fcds_appre

6. Barry M. Staw. (1983). Motivation Research Versus the Art of Faculty Management. The Review of Higher Education, 6(4). 301-321.

7. Basham, Patrick. (1999). Let Marketplace Determine Pay. Winnipeg Free Press. October 25

8. Bercuson, David et al. (1984). The Great Brain Robbery: Canada's Universities on the Road to Ruin. Toronto: McClelland and Stewart.

9. Boyer, Ernest L. (1990). Scholarship Reconsidered: Principles of the Professoriate. Princeton, NJ: Carnegie Foundation for Advancement of Teaching.

10. Christina Wood. (2018). Mastering the Art of Employee Recognition: 9 Things You Can Do Right Now. Retrieved from: http://cio.com/article/3319498/mastering-the art-of-employee-based- Approach.

11. Clifton, Rodney A. and Hymie Rubenstein. (1998). Improving University Teaching: A Performance-Based Approach. Policy Options 19(5):36-39.

12.Coimbatore Institute of Technology (2019) Faculty Induction Program. Under Teaching Learning Center (under Pandit Madan Mohan Malaviya National Mission on Teachers and Teaching Scheme. Dept. of Higher Education, MHRD. GOI.) 
13.Community Tool Box. Section 6 . Developing Staff Orienting Programs

14. Dana Hammer, et al. (2010). Recognition of Teaching Excellence. American Journal of Pharmaceutical Education. 74(9) 164-178. Doi:10.5688/aj7409164 Retrieved from: https://ncb.nlm/pmc/articles/PMC2996754

15.Daniel Druhora. (2017). Students turn to Engineering Diplomacy to Solve $21^{\text {st }}$ Century Grand Challenges. USC Viterbi. https://Viterbischool.Use.Edu/Author/Druhora/

16. Education World. Recognizing the Stars on Your Staff. Retrieved from: https://educationworld.com/a_admin538.shtml

17.Faculty of Engineering. (2019). Industry Partnership and Commercialization. London: Imperial College. https://imperial.ac.uk/engineering/industrypartnership-and-commercialization/

18.Gujarat Technology University. (2019). GTU\&AICTE Sponsored Faculty Development Program on INDUCTION TRAINING for Newly Recruited Faculties. Ahmedabad- GTU

19. Harvard University. Faculty of Arts and Science. Recognizing and Rewarding your Staff. Retrieved from: http://hr.fas.harvard.edu/recognition.

20. Human Resources Department. Faculty of Arts and Sciences. Recognizing and Rewarding Your Staff. Retrieved from: https://hr.fas.harvard.edu/recognition

21. Hymie Rubenstein. (2000). Rewarding University Professors: A Performance-Based Approach. A Fraser Institute Occasional Paper, Public Policy Sources, No. 44. Retrieved from: https://fraserinstitute.org/default/files/Rewardin gUniversityProfessor.pdf

22.Industrial Research \& Development Unit (IRD). (2009). General Information on Sponsored Research Projects \& Consultancy Jobs. New Delhi: Indian Institute of Technology.

23.Indian Institute of Technology, Bombay. (2014). Handbook.
http://iitb.ac.in/sites/default/files/FacultyHandbook-2014.pdf

24. Ite Joya Misra and Jennifer Lundquist. (2016). Making a Difference through Public Engagement. Inside Higher Ed. Retrieved from://insidehighered.com/2016/11/10/importa nce-university-recognition-faculty

25.International Engineering Alliance. (2013). Graduate Attributes and Professional Competencies. Version 3:21 June 2013. https://www.ieagreements.org/assets/uploads/D ocuments-Attributes-and-ProfessionalCompetencies

26.Jeffrey Bodimer. (2019). Use Training and Development to Motivate Staff. https://thebalancecareers.com/use-training-anddevelopment-to-staff-197833

27.Lynn F. Jacobs and Jeremy S. Hyman. (2009). 10 Tips for Success for Engineering Students. US News Education, http://www.usnews.com/education/blogs/profes sor-guide/

28.Mark Crawford. (2012). 9 Self-Improvement Strategies for Engineers. ASME.org. https://www.asme.org/topics-

resources/content/9-selfimprovement-

stragegies-for-engineers

29. Michael Armstrong and Helen Murlis. (2008). Reward Management. A Handbook of Remuneration Strategy Practice, Revised $5^{\text {th }}$ Edition, New Delhi: Kogan Page India Ltd.

30.Mona Holmquist. (2019). Lack of Qualified Teachers: A Global Challenge for Future Knowledge Development. Intech Open. p 1-13.

31.Mohan Reddy B.V.R. (2019). Engineering Education in India-Short and Medium-Term Prospection. https://aicteIndia.org/default/files/Short\%20Term\%20and \%Medium\%20Term\%20Rep

32.NAE Grand Challenges (2006). Engineering for the Developing World

33. National Educational Policy 2019 (Draft), New Delhi: Ministry of Human Resource Development 
34.National Institute for Digital Learning (2019). Consultancy Services. http://www.dcu.ie/nidl/

35.National Institute of Technical Teachers' Training and Research, Bhopal. (2018). Employees their Power, Duties. Manual-II. https://nitttrbpl.ac.in/index.php/manual-ii

36.National Science Foundation. (2020). Research Experiences for Teachers (RET) in Engineering and Computer Science. USA

37. O'meara, K. (2002). Uncovering the Values in Faculty Evaluation of Services as Scholarship. Review of Higher Education. 26(1), 57-80. Retrieves from: http://search.provost.com.ezproxy.rit.edu/docvi ew/62201956?accountid $=108$

38. Ohio State University. Principles of Faculty Reward Systems in a High- Performance Academic Culture. Retrieved from: http://oaa.osu.edu/assets/files/documents/facult yrewardsystems031809.pdf

39.Osmania University- Centre for Professional Advancement \& Continuing Education [CPACE] .(2014). Induction Programme for the Newly-recruited Faculty Members. Hyderabad: UGC Unit, Osmania University.

40.Phil Rabinowitz. (2018). Developing a Plan for Staff Hiring and Training. Section 1. Community Tool Box. https://www.ctb.ku.edu/en/table -of-

45. The Collaborative on Academic Careers in Higher Education Survey. Faculty Job Satisfaction Survey. (2013). Provost's Report. Rochester Institute of Technology. Retrieved from: https://www.rit.edu/provost/files/coache_provost report 2013.pdf.

46.The National Academic Press Open Book. (2004). Attributes of Engineering in 2020. The Engineer of 2020: Visions of Engineering in the New Century. Chapter: 4 NAP.edu/10766. https://www.nap.edu/read/10999/chapter6

47.Veronica Diez, PB Garrett. ED Kinley, John Moore, and Celeste Schwartz. (2009). Faculty Development for the $21^{\text {st }}$ Century. Educause Review. 44(3):46-55 contents/structure/hiring-and-training/developa-plan/main

41. Riordan, C. (2013). Foster a culture of gratitude. HBR Blog Network. Harvard Business Review. Retrieved from: http://blogs.hbr.org/2013/04/foster-a-cultutreof-gratitude/

42. Roberts, K., and Yarrish., J. (2008). Strategies for Improving Faculty Morale and Elevating Performance. University Leadership Council. Education Advisory Board (EAB).

43. Rubenstein, Hymie, and Rodney A. Clinton. (1998). A New Approach to Tenure and Scholarship. University Affairs 39(5):23-24

44.Sarah El-Mallah and Tonia Dousay. (2019). Encouraging Faculty Adoption of Virtual Reality Tools in Engineering Education. https://journals.uair.edu/index.php/itet/article/vi ew/23147/22274

\section{Brief CV of the Author:}

Thanikachalam Vedhathiri, B.E. (1968, Civil Engineering, Univ. of Madras)., M. Tech. (1970, Soil Mechanics and Foundation Engineering, IIT Madras)., Ph.D. (1975, Filter Design for Earth and Rockfill Dams, Univ. of Madras)., M.S. (1988, Instructional System Technology, Indiana University, Bloomington, USA)., FIE., FIGS., FFIUCEE., Guided 18 scholars in the Interdisciplinary Ph.D. in Engineering Education and published around 200 papers and textbooks, research reports, and video programs. Former senior researcher under the Fulbright Scheme of the USA in 1988. 